\title{
TTR
}

Traduction, terminologie, re?daction

\section{The Problem of Trans-lation: Reading French Feminisms}

\section{Bina Freiwald}

Volume 4, numéro 2, 2e semestre 1991

Traduire la théorie

URI : https://id.erudit.org/iderudit/037093ar

DOI : https://doi.org/10.7202/037093ar

Aller au sommaire du numéro

Éditeur(s)

Association canadienne de traductologie

ISSN

0835-8443 (imprimé)

1708-2188 (numérique)

Découvrir la revue

Citer cet article

Freiwald, B. (1991). The Problem of Trans-lation: Reading French Feminisms. TTR, 4(2), 55-68. https://doi.org/10.7202/037093ar d'utilisation que vous pouvez consulter en ligne.

https://apropos.erudit.org/fr/usagers/politique-dutilisation/ 


\section{The Problem of Trans-lation: Reading French Feminisms}

\section{Bina Freiwald}

I would like to introduce my topic - the reception in North America of French feminist theory in translation - by citing an exchange between three American feminist scholars, an exchange occasioned by a 1981 Yale French Studies special issue entitled "Feminist Readings: French Texts/American Contexts." The participants in this forum were invited to talk about their responses to French feminist thought, and, not surprisingly, their conversation soon turned to the subject of translation as a matter of vital and pressing concern:

Susan Gubar: I would just speak for a moment about the people that I feel are bridge figures between French theoretical/critical thinking and the American literary historical establishment. ...I wonder if other people feel the same sort of dependence on those figures who really do crucially important translations (trans-lations) carrying across from one culture to another, from one language to another, and from one set of ideas to another.

Carolyn Allen: I feel the same dependency especially in reading French writers whose French is very taken up with word play, but it frustrates me. You can't always tell how much has been lost in translation. And my experience has been that other American feminist critics are also dependent on what has been translated.

Sandra Gilbert: And you understand what you are trying to do without when you see how fascinating the work done in 
France is and how essential it certainly seems. But at the same time, I have to say that I do feel troubled and excluded by it sometimes. I tend to feel that they are very opaque. Even when my French is good enough, it's still so much an "other" culture. That makes it both fascinating and fearful, and extraordinarily glamorous. It seems to me that what we need is, in fact, not just mediations, but mediations of mediations. (pp. 6-7; emphasis added)

I find the disclosures and self-disclosures in this conversation thought-provoking and suggestive in a number of ways. First, I cannot fail to notice how affectively charged this exchange is, how it brings to the fore anxieties and frustrations associated with the very need for the raison d'être of - translation. For Gilbert, Allen and Gubar, the dependence on the linguistic and semiotic mediation of translation is an unwelcome and disturbing experience, an experience which triggers anxieties about the impenetrable foreigness of another tongue (an other's tongue), about loss of control over the communicative process, anxieties arising from a sense of being condemned to a state of linguistic and cognitive exile, and of being cut off from the vital sources of authentic meaning and expression. In a first instance, then, we observe that an integral part of the overall response to this body of theory as it becomes available in translation is a specific response to the very fact of translation - in other words, a reaction to the experience of being (inescapably) subjected to/dependent on discursive mediation. In their engagement with the difference that translation makes, moreover, the participants further challenge us to think of translation as a critical discursive practice, an intervention which works to expose - in the sense of foregrounding, of rendering opaque and visible - precisely that in discourse which is untranslatable because it is culturally specific: that which has to be trans-lated, accounted for, mediated. In the words of the editors of the Yale French Studies special issue: "The problem of trans-lation [...] goes beyond words to broad differences in cultural context" (p. 7).

My present discussion is part of a larger project in which I look at the reception of French Feminist theory in North America over the last fifteen years; my particular emphasis here will be on the initial configuration at the point of emergence of this critical discourse. The 
broader parameters of my project involve an examination of the extent and nature of the engagement of North American feminist literary critics with French feminist theories in translation. Relating to aspects of literary production, I am interested in questions regarding the range of French theoretical texts that have become available in English translation since the mid-seventies, looking at issues such as: who are the theorists who have been translated and who/why have others been excluded? What forms did the introduction of these new theories take (e.g., an essay in a special issue of a particular kind of scholarly journal; a book with a preface by a North American critic who is identified with a particular theoretical orientation, etc.), and to what extent did these choices create interpretive contexts that might have affected the reception of the works in translation? What was the immediate response in American and Canadian feminist literary circles to these publications? These considerations in turn lead me to examine the interpretive process by which these translated theoretical texts have been represented in and incorporated into the discourse of North American literary feminists particularly since the early eighties (the publication of Elaine Marks and Isabelle de Courtivron's New French Feminisms in 1981 marks a significant turning point). I am interested in investigating the challenges/difficulties that the 'difference' of the French theoretical texts has presented for these critics, both at the level of linguistic expression - certain terms, like "jouissance" and "écriture féminine," have proven untranslatable - and at the level of critical and ideological conceptualization - involving difference in the understanding of such key notions as subjectivity and history. For the purposes of the present discussion, I will be foregrounding the role of those "mediations of mediations" Gilbert finds so invaluable: those interpretive texts and contexts in which a translation is embedded and which attempt to render more legible the linguistic and semiotic dialogue between cultures that is constitutive of the text in translation.

To further identify the nature of my own critical intervention in this scene, I would like to comment on what has drawn me to take a closer look at the complex of linguistic and cultural transactions that constitute the fate of texts in translation, and on what has in particular aroused my curiosity about the response of American literary feminists to their French counterparts. My theoretical thinking on translation has been marked by Bakhtine's writing on heteroglossia and dialogism. 
More recently, a critical text by Caryl Emerson on the centrality of the concept of translation to Bakhtin's thought has had a powerfully personal resonance for me. Emerson writes:

[...] translation, broadly conceived, was for him [Bakhtine] the essence of all human communication. Crossing language boundaries was perhaps the most fundamental of human acts. Bakhtine's writing is permeated by awe at the multiplicity of languages he hears. These are not just the bluntly distinct national languages - Russian, English, French - [...] but also the scores of different "languages" that exist simultaneously within a single culture and a single speaking community. In fact, Bakhtine viewed the boundaries between national languages as only one extreme on a continuum; at the other extreme, translation processes were required for one social group to understand another in the same city, for children to understand parents in the same family, for one day to understand the next. These stratifications of language, Bakhtine argued, do not exclude one another; they intersect and overlap, pulling words into various gravitational fields and casting specific light and shadow. [...] this means that every speaking subject speaks something of a foreign language to everyone else. It also means that every speaking subject has more than one native language at his [sic] disposal. To understand another person at any given moment, therefore, is to come to terms with meaning on the boundary between one's own and another's language: to translate. (Dostoevsky's Poetics, p. xxix, emphasis added)

I recognize in Bakhtine's primal scene of translation my own polyglotic beginnings in which as a first generation Hebrew-speaking native Israeli I was born into multiple tongues: Hebrew, a national mother-tongue in the process of self-birthing, my native tongue but not my mother's; Bulgarian, my mother's mother-tongue but not her mother's (who came from Turkey via Greece); Ladino, my paternal grandmother's mother-tongue, the only language she could speak with fluency, itself a hybrid of 15th century Spanish and a host of other languages marking it as a product of a linguistic history of exile, persecution and assimilation (a history that would also mark it as a 
woman's tongue, a literally mutilated domestic idiom in which the vocabularies of the public sphere had atrophied and died). Ours was a typical Israeli household of the 50's, one in which linguistic heterogeneity was inextricable from cultural but also personal difference, and in which those differences were as much inter-personal and they were intra-personal, that is, vectors of difference traversing us as individual subjects and constituting us as a collectivity. Those linguistic negotiations between Hebrew, Bulgarian, Turkish and Ladino were also cross-generational negotiations as much as they were internalized political and cultural negotiations. Translation was as inescapable as language itself, the foreigness of one's utterance an integral dimension of language use, the openess/vulnerability of one's idiom to mistranslation and misrepresentation what came with the only territory one knew. I was hardly surprised, then, to find out that the initiators of the dialogue between French and American feminisms were women of plural personal and/or professional origins, women like Domna Stanton who wrote of her speaking position in an 1977 issue of Tel Quel: "Qui répète ce discours? Qui re-parle? Moi/elle, Grecque enseignant le français aux États-Unis. Polyglotte sans glotte à moi, comme toute femme d'ailleurs, Européenne en Amérique et Américaine en Europe." (p. 119)

What has even more specifically provoked me into thinking about the process of cultural translation as it is documented in the reception of French feminist theory by American feminists is an essay by Sandra Gilbert and Susan Gubar entitled "The Mirror and the Vamp: Reflections on Feminist Criticism" which came out in 1989 in an Anthology with the hopeful title The Future of Literary Theory. In their essay Gilbert and Gubar mount an ad feminam attack on that unholy trinity Cixous, Irigaray, and Kristeva who, according to Gilbert and Gubar, "practice the arts of the vamp" (p. 151). Both femme fatale and vampire, the vamp is "delectably sensual and transgressive," but also dangerously glamorous, for she not only "suck[s] the blood of male theory" (p. 152) but "the drama of seduction and betrayal that she enacts in her foray against patriarchal structure may end up being as seductively treacherous to women as to men" (p. 154). Gilbert and Gubar warn us against "the boundless ambition of the vamp, whose intellectual striptease ultimately displays not the recalcitrant autonomy of the world of the text but the naked brilliance of the text of her 
desire" (p. 156). "[T]he naked brilliance of the text of her desire." Whose desire, exactly? I started wondering as I recalled Gilbert's much earlier and revealing comment in the special issue of Yale French Studies mentioned above. Less guarded perhaps due to the conversational mode, Gilbert spoke there of the "'otherness'" of the "French feminist theoreticians," confessing that those "wistful fantasies" leave her "faint with desire" (p. 10). More on this repressed American libido later.

One could perhaps see 1976 as the year that French feminist theory is officially legitimated as an intellectual import in North America. This would be my reading of the inclusion in the first issues of Signs: A Journal of Women in Culture and Society of translated excerpts from Kristeva's "Des Chinoises" and a translation of Cixous' "le Rire de la méduse." Signs, arguably the single most visible (and perhaps most authoritative) scholarly publication in the field of women's studies, has since then continued to contribute to this trans-cultural exchange. Two essays in Signs $(3: 4,1978)$ are considered to constitute the first in-depth analysis of French feminism for an American audience (see Irene Finel-Honigan); these are Elaine Marks' "Women and Literature in France" and Carolyn Burke's "Report from Paris: Women's Writing and the Women's Movement." I would argue, however, that the terms of the discussion - the frame of reference within which French theoretical texts would subsequently be viewed as they become available in translation - had already been suggested by Shoshana Felman in a trend-setting review-article in the Winter 1975 issue of Diacritics, in which Felman discusses Luce Irigaray's Speculum de l' autre femme and Phyllis Chesler's Women and Madness (Speculum, published in 1974 will not be translated until 1985, the year that Irigaray's 1977 Ce sexe qui n'en est pas un also appears in English translation). Felman wrote in 1975 , thereby possibly sealing the discursive fate of French feminist fortunes in North America for at least a decade to come:

In a sense, the difficulty involved in any feminist enterprise is illustrated by the complementarity, but also by the incompatability of the two feminist studies which we have just examined: the works of Phyllis Chesler and Luce Irigaray. The interest of Chesler's book, its overwhleming persuasive power 
[...] lies in the fact that it does not speak for women: it lets women speak for themselves. Phyllis Chesler accomplishes thus the first symbolical step of the feminist revolution: she gives voice to the woman. But she can only do so in a pragmatic, empirical way. As a result, the book's theoretical contribution, although substantial, does not go beyond the classical feminist thought concerning the socio-sexual victimization of women. On the other side of the coin, Irigaray's book has the merit of perceiving the problem on a theoretical level, of trying to think the feminist question through to its logical ends, reminding us that women's oppression exists not only in the material, practical organization of economic, social, medical, and political structures, but also in the very foundations of logos, reasoning and articulation - in the subtle linguistic procedures and in the logical processes through which meaning itself is produced. (p. 4)

By 1978 Felman's distinction between an empirical and a theoretical formulation of feminist issues - a distinction she presents as interior to a feminist project broadly conceived - is exteriorized (ex-territorializied one might say) and nationalized, translated, in other words, into a conflictual national-cultural paradigm whose fixed points of reference are American vs French. An illustrative example is Elaine Marks' ground-breaking essay "Women and Literature in France." Marks uses as epigraph for the essay Cixous' battle cry from "The Laugh of the Medusa": "Let the priests tremble, we're going to show them our sexts" [sex\&texts], but her very opening sentence already affects a displacement, for the scene before us is no longer that of the battle of the genders but that of trans-Atlantic intellectual rivalry and ideological strife: "Not yet even a dialogue, some traces of American/French differences regarding women and literature now and then appear . [...] Usually, on this side of the Atlantic, there is dismissal (too intellectualistic and elitist to be feminist)" (p. 832). Both Marks' essay, and Carolyn Burke's essay in the same issue, exhibit certain features which seem to be more characteristic of the early essays on French feminist theory, essays written by American theorists who engage directly with the French original texts (before translations become available). The most important distinguishing features of these 
early assessments appear to me to be: first, an awareness of diversity and heterogeneity within French feminist theory (the differences between Monique Wittig and the group around Questions Féministes, and Hélène Cixous and the group Politique et Psychanalyse, for example); and second, a recognition that certain key terms are untranslatable because of a complex cultural grounding that cannot possibly be conveyed or even suggested by the target language. This recognition leads the early mediators of French feminist theory to an emphasis on the need for cultural translation to accompany the linguistic translation, and underlies their practice of providing an interpretive explanatory apparatus around key words which are kept in the original French. To give a few examples: Burke leaves in French "prise de conscience," "prise de la parole," and "prise de pouvoir," commenting on her decision: "It is difficult to translate all the echoes of the phrase 'prendre la parole'; 'prendre le pouvoir' immediately comes to mind. La parole and its cousin, le verbe ('the word,' the Logos in the full theological sense), have been until recently the possessions of a small, well-educated male elite" (pp. 844-845). Burke also does not translate "[student] revendications," "l'écriture" and "la venue à l'écriture," "langage des femmes," and "jouissance." Marks retains "écriture féminine," explaining that "the adjective féminin(e) is frequently used today in such expressions as écriture féminine or sexualité féminine, not in the judgmental sense of a stereotypical woman's nature but in the classificatory sense of pertaining to women. This also applies to the noun féminité" (p. 833). Marks also glosses "le continent noir" (p. 835) and "Jouissance": "Jouissance in French signifies pleasure, usually sexual pleasure. The expression jouissance feminine stresses the difference between the male and female libidinal economies. Jouissance féminine is a central concept in most texts published on women's sexuality, women's libido, women's desire" (p. 835).

One of my principal arguments here, about the crucial role played by those second degree cultural mediations Gilbert speaks of mediations which can take the form of explicitly interpretive translations or explications of the translated text - could perhaps be best illustrated by putting next to Marks' gloss on "jouissance" two other glosses on the same word, by the translators of Kristeva and Cixous. Leon Roudiez's "Notes on the Translation and on Terminology" which introduces Kristeva's Desire in Language foregrounds the multiplicity of meanings 
which attach themselves to "jouissance," including "denotations covering the field of law and the activity of sex" so that "jouissance is sexual, spiritual, physical, conceptual at one and the same time [...] also through the working of the signifier, this implies the presence of meaning (jouissance $=$ j'ouis sens $=\mathrm{I}$ hear meaning)" (p. 16). The entry "jouissance" in Betsy Wing's 'Glossary' appended to her translation of Cixous' The Newly Born Woman (1986) reads:

Total sexual ecstasy is its most common connotation, but in contemporary French philosophical, psychoanalytic, and political usage, it does not stop there, and to equate it with orgasm would be an oversimplification. It would also [...] be inadequate to translate it as enjoyment. This word, however, does maintain some of the sense of access and participation in connection with rights and property. It is, therefore, a word with simultaneously sexual, political, and economic overtones. Total access, total participation, as well as total ecstasy are implied. [...] On the phonic level, one car hear: jouissance: j'ouis sans: I hear meaning. [...] In La Jeune Née, the disturbance leading to hysteria [...] is often something heard but not yet understood [...] In the case of the hysteric, "what is heard" provides the clue for these driven women that all is not as it seems, all is not well (p. 165).

Had this fuller cultural translation of "jouissance" been better recognized, we might have been spared over a decade of dismissive American coy righteousness, annoyingly accompanied by repeated accusations of essentialist biologistic determinism and inexplicable fainting spells at the mere mention of the word. The inclusion of glossaries in editions of theoretical texts in translation, it therefore can be argued, involves more than an attempt to account for untranslatable word play. In making the explanatory apparatus an integral part of the project of translation, translators and editors can more fully acknowledge the density of the source text, recognizing the impossibility of separating text from intertext, primary work from interpretation.

Compared to translations, which are first degree cultural mediations, second degree mediations - that is, commentaries on 
translations - are perhaps more likely to be implicated in a cultural power dynamic that positions the interpreter on the other side of the cultural divide. Marks' essay demonstrates this point well, for a particularly intriguing aspect of Marks' voice arises from a self-positioning which appears pre-scripted by the inter-national model. In. her essay, a conflictual nationalistic paradigm is naturalized and rendered rhetorically all the more effective through the alignment of personal pronouns, that is, through the discursive attribution of subjectivity to a collective American "we" and alterity to a collective French "they." [I should parenthetically note here that my analysis is indebted to the work of the linguist Émile Benveniste. Identifying the oppositions that differentiate the persons, Benveniste remarks that "person is inherent only in the positions ' $I$ ' and 'you'. The third person, by virtue of its very structure, is the non-pérsonal form of verbal inflection" (p. 199)]. Marks reassures a rhetorically constructed "us": "Literary criticism that resembles ours is still being produced [in France]" (p. 833), while concluding that "the fundamental dissimilarity in the American/French orientation can be attributed to this differing emphasis [that is, the French emphasis on repression, the American emphasis on oppression]." Marks' final judgment is delivered with the full force of an alleged axiomatic truth: "We raise consciousness by speaking to and working with each other; they explore the unconscious by writing" (p. 842; emphasis added).

Marks' formulation is indeed so powerful that it quickly becomes the accepted doxa. We find it quoted by Alice Jardine in her "Prelude: The Future of Difference," a brief manifesto-like piece that introduces the collection of essays entitled The Future of Difference, co-edited by Jardine and Hester Eisenstein (1980). The Future of Difference will in turn become an authoritative source and indispensable point of reference for subsequent reflections on what Domna Stanton calls in her essay in this collection "the Franco-American Dis-Connection." Jardine, who like Gilbert has lived to experience the thrill of 'la chose française' - "I spend my life walking the tightrope of contradictions between the French and American feminist stances" (p. xxvi) - restates the case as it will be handed down from mediators of mediations like herself and Marks to such influential movers and shapers of the American literary-feminist scene as Elaine Showalter and Gilbert and Gubar: 
As Elaine Marks has put it, American feminists emphasize the oppression of woman as sexual identity, while French feminists investigate the repression of woman as difference and alterity in the signifying practices of the West. To quote Marks, "we raise consciousness by speaking to and working with each other; they explore the unconscious by writing." That is to say, we use words like autonomy and power; they use words like phallocentrism and that word for pleasure which defies translation, jouissance. (p. xxvi)

"We" and "they." The insistence on these plural subjectivities and communal agencies is telling. As I rush into an inconclusive conclusion, I also remember that beleaguered American libido I temporarily abandoned some pages ago. My thoughts turn to a possible connection between Gilbert's simultaneous fear of and attraction to that libidinal Other untamed by translation, and the abandonment of the singular voice in favor of the collective "we" in the essays by Marks, Jardine, and Gilbert's own strained introduction to The Newly Born Woman. A connection suggests itself as I scrutinize a particular second-degree mediation of the kind called for by Gilbert as an indispensable guide into the dark continent of French feminist theory. In an essay in The Future of Difference that proves to be a veritable breeding ground for "we"s, Domna Stanton quotes from Cixous' $\mathrm{La}$ Jeune Nee, a text that at the time of the writing of the essay is not yet available in English translation. The passage Stanton translates for her readers includes an exchange between Cixous and Clement on the conditions for social change. Stanton's mediation here - which collapses the very distinction between first and second degree mediations since she is both translating and interpreting (through selection and commentary) - is illustrative of the complexity of the issues I have been raising. In her translation Stanton retains from the original text observations concerning language and revolution: "But there is no revolution without a coming into awareness [...] we can move nothing when we cease to communicate" (p. 81). What she chooses not to translate, what she leaves out is precisely Cixous' different awareness, her emphatic call for the harnessing of a different, libidinal, force: "I think that what cannot be oppressed, even in the class struggle, is the libido - desire; it is in taking off from desire that you 
will revive the need for things to really change." (The Newly Born Woman, trans. B. Wing, p. 157)

Stanton's selective translation, and the other examples of interpretive linguistic and cultural translation cited above, demonstrate the risk we run, when engaged in translation, of silencing the other in her cultural and linguistic specificity. A monologic national paradigm which pits "us" against "them," and an implicit theory/ideology of translation which sees in translation - as a process of linguistic and cultural mediation - a means of enhancing the collectivity's sense of itself (a way of constructing a stronger "we"), end by condemning the other text/other woman to an alterity that cannot be recognized as an identity as long as the collectivity perceives in that alterity a threat to the very space, - the national, territorial, intellectual, and psycho-sexual space - that the collectivity wishes to inhabit and lay claim to. What is needed, I would venture, are not simply more mediations of mediations, as Gilbert would have it. What is needed is a reconceptualization of the negotiation between linguistic and cultural idioms, in such a manner that a dialogue of languages replaces an imperialism that seeks in the other only a confirmation of its selfsame.

Concordia University

\section{References}

BENVENISTE, Émile (1971). Problems in General Linguistics. Trans. by Mary Elizabeth Meek. Coral Gables, Fla, Univ. of Miami Press.

BURKE, Carolyn Greenstein (1978). "Report from Paris: Women's Writing and the Women's Movement." Signs, 3.4, pp. 843-855.

(1981). Rev. of New French Feminisms, Elaine Marks and Isabelle Courtivron eds. Signs, 6.31, pp. 515-517.

CHAMBERLAIN, Lori (1988). "Gender and the Metaphorics of Translation." Signs, 13.3, pp. 454-472. 
CIXOUS, Hélène \& Catherine Clément (1986). The Newly Born Woman. Trans. by Betsy Wing. Introduction by Sandra $\mathbf{M}$. Gilbert. Minneapolis, Univ. of Minnesota Press.

EMERSON, Caryl (1984). "Editor's Preface" in Bahktin, M.M. Problems of Dostoevsky's Poetics. Trans. by Caryl Emerson. Minneapolis, Univ. of Minnesota Press.

FELMAN, Shoshana (1975). "Women and Madness: The Critical Phallacy." Diacritics (Winter).

"FEMINIST READINGS: French Texts/American Contexts" (1981). Special issue of Yale French Studies, 62.

FINEL-HONIGMAN, Irene (1981). "American Misconceptions of French Feminism." Contemporary French Civilization, 3, pp. 317-25.

GILBERT, Sandra M. \& Susan Gubar (1989). "The Mirror and the Vamp: Reflections on Feminist Criticism." The Future of Literary Theory, ed. by Ralph Cohen. New York \& London, Routledge, pp. 144-166.

JARDINE, Alice. "Pre-Texts for the Transatlantic Feminist." Feminist Readings, pp. 220-236.

\& Hester Eisenstein, eds (1985). The Future of Difference. New Brunswick, N. J., Rutgers Univ. Press (first published 1980).

(1985). Gynesis: Configurations of Woman and Modernity. Ithaca and London, Cornell Univ. Press.

KRISTEVA, Julia (1980). Desire in Language: A Semiotic Approach to Literature and Art. Ed. by Leon S. Roudiez. Trans. by Thomas Gora, Alice Jardine, Leon S. Roudiez. New York, Columbia Univ. Press. 
MARCIL-LACOSTE, Louise (1980). "The Grammar of Feminine Sexuality." Canadian Journal of Political and Social Theory, 4.2, pp. 69-74.

MARKS, Elaine (1978). "Women and Literature in France." Signs, 3.4, pp. 832-842.

MELMAN, Deborah (1980). "Feminist Explorations: Life under Patriarchy." Canadian Journal of Political and Social Theory, 4.2, pp. 64-68.

RICHMAN, Michèle (1980). "Sex and Signs: The Language of French Feminist Criticism." Language and Style, 13.4, pp. 62-80.

STANTON, Domna (1977). "Parole et écriture: Women's Studies, USA." Tel Quel, 71/73 (Autumn), pp. 119-135.

"Language and Revolution: The Franco-American Dis-Connection." The Future of Difference, pp. 73-87. 